\title{
Exploring Informal Education for Promoting Mental Health Literacy: A Study to Youth in Malaysia
}

\author{
Muhammad Nur Waafi Badruldin, Siti Raba'ah Hamzah, Faiq Aziz \& Nur \\ Fazreen Aina Muhammad
}

To Link this Article: http://dx.doi.org/10.6007/IJARBSS/v11-i12/11598

DOI:10.6007/IJARBSS/v11-i12/11598

Received: 03 October 2021, Revised: 04 November 2021, Accepted: 26 November 2021

Published Online: 13 December 2021

In-Text Citation: (Badruldin et al., 2021)

To Cite this Article: Badruldin, M. N. W., Hamzah, S. R., Aziz, F., \& Muhammad, N. F. A. (2021). Exploring Informal Education for Promoting Mental Health Literacy: A Study to Youth in Malaysia. International Journal of Academic Research in Business and Social Sciences, 11(12), 1221-1236.

Copyright: (c) 2021 The Author(s)

Published by Human Resource Management Academic Research Society (www.hrmars.com)

This article is published under the Creative Commons Attribution (CC BY 4.0) license. Anyone may reproduce, distribute, translate and create derivative works of this article (for both commercial and non0-commercial purposes), subject to full attribution to the original publication and authors. The full terms of this license may be seen at: http://creativecommons.org/licences/by/4.0/legalcode

Vol. 11, No. 12, 2021, Pg. 1221 - 1236

Full Terms \& Conditions of access and use can be found at http://hrmars.com/index.php/pages/detail/publication-ethics 


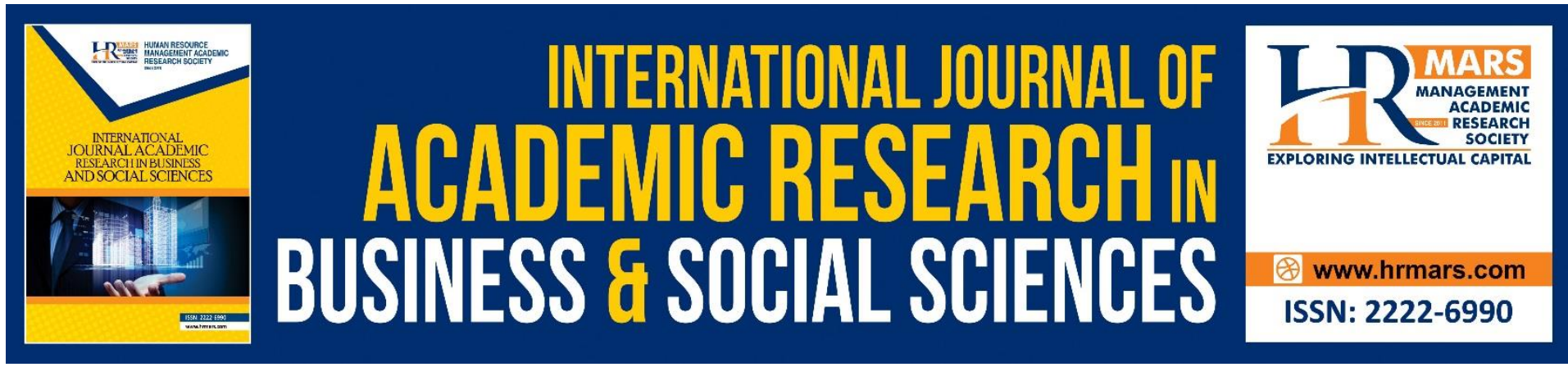

\title{
Exploring Informal Education for Promoting Mental Health Literacy: A Study to Youth in Malaysia
}

\author{
Muhammad Nur Waafi Badruldin, Siti Raba'ah Hamzah, Faiq \\ Aziz \& Nur Fazreen Aina Muhammad \\ Faculty of Educational Studies, Universiti Putra Malaysia, 43400, Serdang, Selangor Darul \\ Ehsan, Malaysia.
}

\begin{abstract}
The study aimed to explore the role of informal education in promoting mental health literacy among Malaysian youth. Semi-structured interviews were conducted with six practitioners and group focus interviews with university youth. The comprehensive view of the role of informal education in promoting mental health literacy that emerged from the interviews included family members providing emotional support and social therapy. In addition, nongovernmental organizations promote mental health management methods and other activities related to mental health literacy, role from peers with socialising others, and mass media become an influencer to the youth, social media page related to mental health has a positive influence on youth, expert and caregiver officers act actively by performing the process of recognizing, acknowledge and contribute. The themes found addressed the understanding of promoting mental health literacy among youth in Malaysia.
\end{abstract}

Keywords: Mental Health Literacy, Youth, Informal Education, Qualitative, Malaysia

\section{Introduction}

The field of education offers a direct and indirect contribution to the improvement of mental health literacy $(\mathrm{MHL})$. This refers to the improvement of knowledge related to mental health management, practice in daily life, and the formation of attitudes in an individual. There are three existing education patterns which are formal education (FE), non-formal education (NFE) and informal education (IE) (Marsick \& Watkins, 2001) have been practiced by most communities in Malaysia (Ministry of Education Malaysia, 2015). The formal educational styles involve educational institutions providing opportunities to improve mental health literacy. In structured educational institutions, several aspects, including classroom-based educational activities, health services, extracurricular activities, and mental health promotion, have been used at various levels of existing educational institutions, such as primary school, secondary school, and university. This is because the involvement of formal and non -formal education on the aspect of promoting mental health literacy among youth in Malaysia has been widely practiced as for example in the aspect of formal education is placed curriculum related to mental health to provide knowledge and information related to mental health to the target group. 
This can be seen in the learning environment in schools involving primary and secondary school students. This all happens and the application is in school only, whereas more time is spent by most students is at home and with the local community. Daily activities and programs that take place outside of school hours have more potential to be developed and in turn have more benefits and positive effects on youth mental health literacy. The percentage of students in school is only $27 \%$, the rest of the time with family at home (Ministry of Education Malaysia, 2013). In terms of non-formal education, a series of forums, awareness seminars, campaigns and so on have been conducted, but from the point of view of informal education where the learning process takes place in daily life such as through mass media and social media is still less emphasized in the barriers of media practitioners to disseminate knowledge and promote aspects of mental health literacy. The following diagram can illustrate the relationship of the field of education and the contribution as well as the relevance in promoting $\mathrm{MHL}$ to the youth.

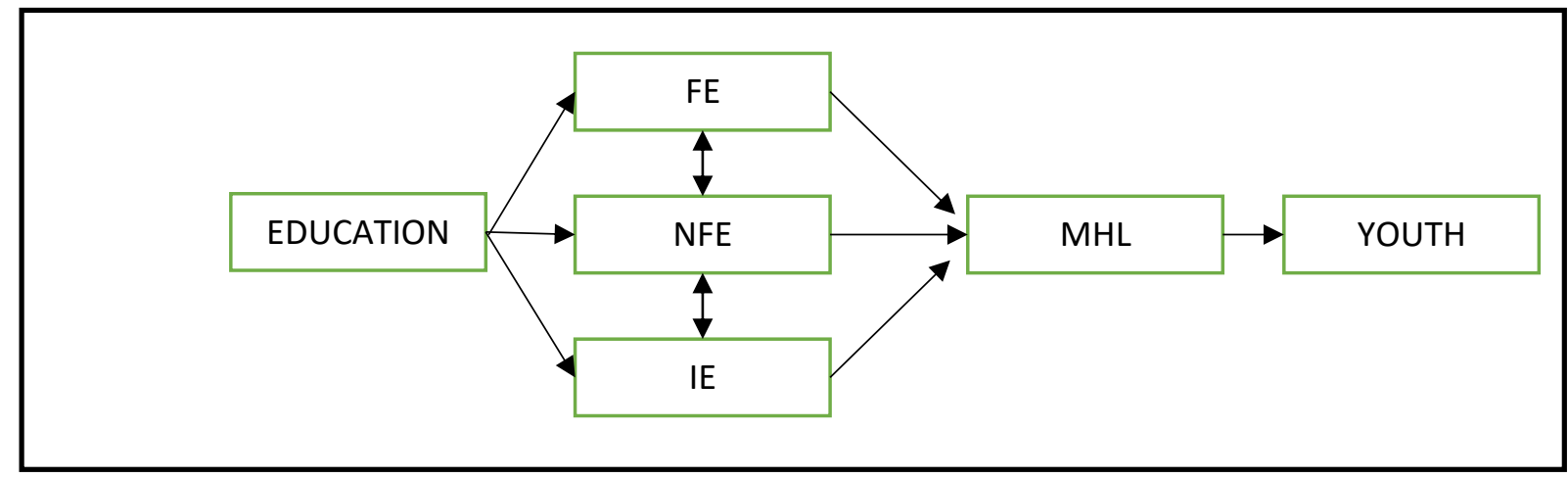

Figure 1: Education Category To Promote MHL Among Youth

It is necessary to provide the perfect knowledge to the community, parents and youth themselves to be more aware of the importance of having a good level of mental health literacy in order to continue the process of sustainable youth development, perfect community development and thus contribute to better society development in daily life (Larsen, 1987). In implementing these precautionary measures, some steps need to be taken including social and psychological treatment involving parents, peers and others who are considered to be informal in taking steps to cure people with mental health disorders in Malaysia especially the youth. In addition to communicating well with peers and close family members can assist them in addressing mental health issues and in turn have friends who can assist in supporting the situation for youth living as individuals with good mental health (Delprino, 2017). Peer education activities can involve a variety of informal and formal influences (Backett-Milburn, 2000). In addition, the influence of peers can also guide a person to increase motivation towards a more prosperous quality of life (Lizzio et al., 2011). Such a peeragogical approach is also said to be a method of education that is more in line with the needs of today's society by complementing previous methods such as pedagogy, heutagogy and andragogy (Chan et al., 2019).

\section{Literature Review}

Informal education is a lifelong process in which each individual acquires attitudes, values, skills and knowledge from daily experience and the influence and educational resources in his 
or her environment - from family and neighbors, from work and play, from markets, libraries and mass media (Farahani et al., 2014; Johnson, 2017). Past studies show that youths seek treatment and help from informal education agencies, and sometimes are unable to meet the needs and wants of the youths in solving existing problems (Bavarian et al., 2020; Lam, 2014; Mandalia et al., 2018). It indirectly involves the atmosphere in an individual's home, health care and encouragement, as well as the involvement of family members who indirectly acts as an informal educator in conveying messages from a professional to individuals involved with mental health problems (Ministry of Health Malaysia, 2013). Other studies suggest that the involvement of family members and friends is often defined as informal caregivers (Berry et al., 2019). This group can provide very significant and invaluable support to those with mental health problems (Hannan, 2013). As a result, there has been an increased emphasis on the need for better care planning and prevention through health education methods between community service, patients and their informal caregivers (Clegg et al., 2020; Jones et al., 2018). Family members who associate with those with mental health problems, whether adolescents or youths who are part of the moral support system, should play and show positive values to ensure good emotional and stress management. Therefore, this informal education agent requires perfect understanding and education and strong motivation to launch the process of improving mental health literacy inadvertently. However, negative reactions from family members and friends need to be exposed and resolved with a proper understanding related to mental health. The figure below explains the concept of informal education within the scope of this study. 


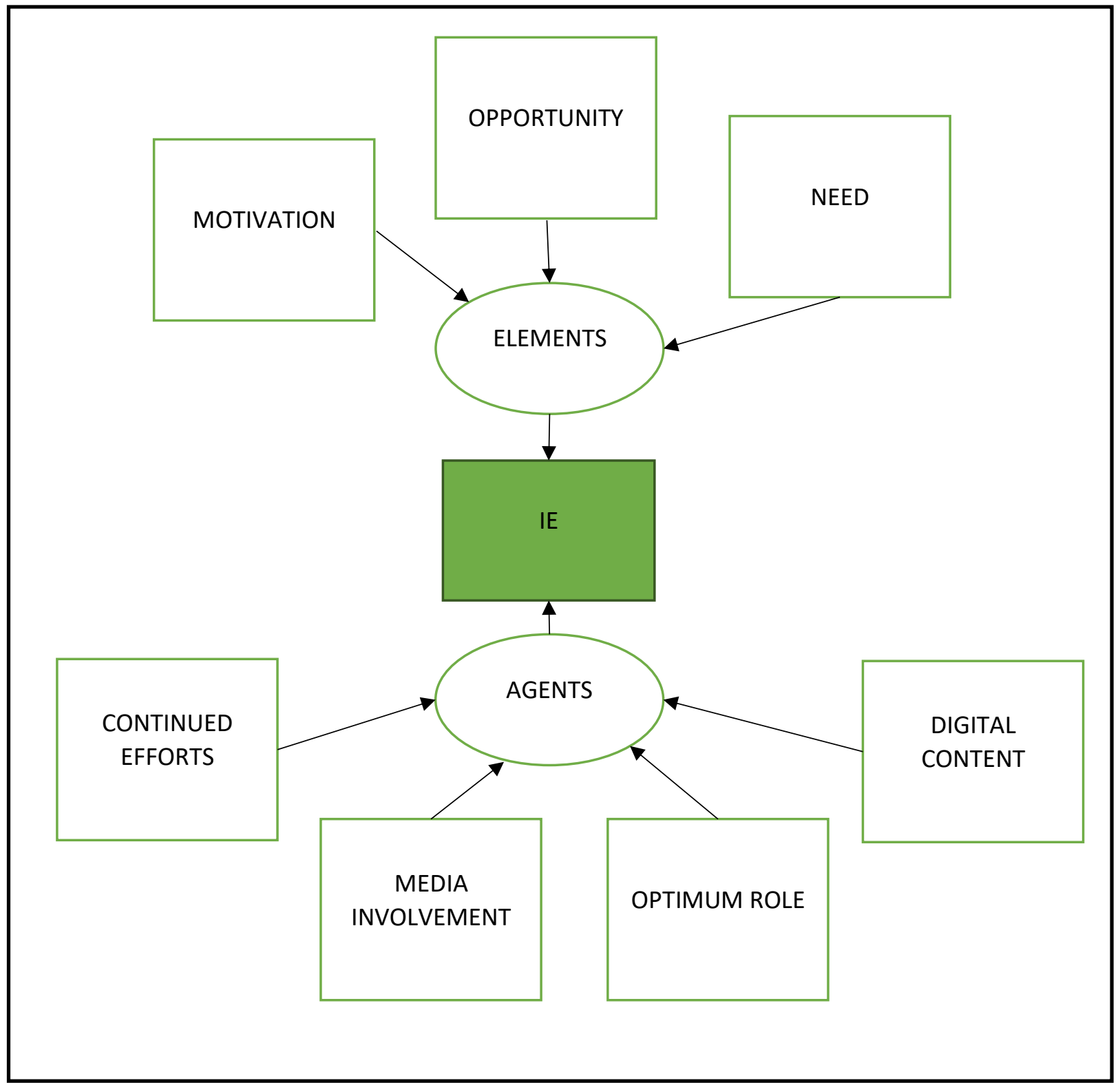

Figure 2: Informal Education Concept Related to MHL Promotion

Informal educational elements such as high motivation and desire (to help) for youth need to be clearly understood by the agent closest to the atmosphere of a youth's life. Generally, more teenagers and youths meet with parents and peers to express their feelings and talk about personal problems. No less also those who express themselves in social media nowadays (Mpungose, 2020). The informal educational process in curbing mental health problems is also done by leveraging technology (Clarke et al., 2014; Hui et al., 2015; Kauer et al., 2014; Pretorius et al., 2019; Richards \& Tangney, 2008; Tay, 2018). In recent decades, information and communication technology (ICT) is widely used by many parties. Its interventions maintain priority, are comprehensive, easily accessible, cost-effective, and reach billions of people at any one time (Tennant et al., 2015; World Health Organization, 2013). In this regard, the role of the mass media in the mainstream should be played out better than to encourage people with mental illness with a negative outlook to be used to enhance positive prejudice against those affected by mental health issues (Kelly et al., 2007; 
Tudor, 2013). How does the perspective of those around them look at this matter? A positive daily process will give good trust to all members of society in solving mental health problems.

In this study, we want to describe the current understanding of mental health literacy and how it is realised in a community the informal education for mental health literacy improvement, as defined by informal education agents from the domains of psychiatry, psychologists, and the youth themselves. This includes their opinions on applying elements of informal education in society while answering how informal education agents apply their role to be better for Malaysian youth and thus contribute to a positive self-development process.

\section{Method}

In this exploratory study, we used a qualitative methodology. In qualitative research, the main research instrument is researchers. The researcher sought to determine the focus of the study, selecting informants as sources data, collect data, evaluate data quality, analyze and interpret data and draw conclusions. For data collection, we run six semi-structured interviews with mental health professionals from various agencies and one focus group discussion session with ten university students from March 2020 to Nov 2020. Respondents' clinical and non-clinical experience between 2 to 30 years was assessed in detail. The interviews took place at their workplaces and via an online medium (due to the covid pandemic season). The data collection activities in conducting this study required individuals from several fields who have been involved in improving and enhancing mental health literacy (either directly or indirectly) which is also a major topic for this study. Selection of respondents that aims to help determine the appropriate informant. This includes also from among young people who also act as peers in improving mental health literacy. The interview is run for approximately 50 minutes to 1 hour at each interview session conducted. The interview guide covers respondents' perceptions of aspects such as understanding the concept of mental health literacy, attitudes towards people with mental health problems, and barriers or challenges in strengthening mental health literacy. The table below shows the list of respondents: 
Table 1. Selected Informant Details

\begin{tabular}{|c|c|c|c|c|}
\hline $\begin{array}{l}\text { Number / } \\
\text { label }\end{array}$ & $\begin{array}{l}\text { Collection data } \\
\text { type }\end{array}$ & Agency / party & Position/career & $\begin{array}{l}\text { Time } \\
\text { /medium }\end{array}$ \\
\hline $\begin{array}{l}\text { Informant } \\
1\end{array}$ & $\begin{array}{l}\text { Semi-structured } \\
\text { interview }\end{array}$ & $\begin{array}{l}\text { Private } \\
\text { University }\end{array}$ & Psychologist & $\begin{array}{l}\text { Mac 2020/ } \\
\text { face to } \\
\text { face } \\
\text { meeting }\end{array}$ \\
\hline $\begin{array}{l}\text { Informant } \\
2\end{array}$ & $\begin{array}{l}\text { Semi-structured } \\
\text { interview }\end{array}$ & $\begin{array}{l}\text { Public } \\
\text { University }\end{array}$ & $\begin{array}{l}\text { Youth } \\
\text { (university level) }\end{array}$ & $\begin{array}{l}\text { May 2020/ } \\
\text { online } \\
\text { zoom } \\
\text { meeting }\end{array}$ \\
\hline $\begin{array}{l}\text { Informant } \\
3\end{array}$ & $\begin{array}{l}\text { Semi-structured } \\
\text { interview }\end{array}$ & $\begin{array}{l}\text { Public } \\
\text { University }\end{array}$ & $\begin{array}{l}\text { Practitioner } \\
\text { /Psychologist }\end{array}$ & $\begin{array}{l}\text { May 2020/ } \\
\text { online } \\
\text { zoom } \\
\text { meeting }\end{array}$ \\
\hline $\begin{array}{l}\text { Informant } \\
4\end{array}$ & $\begin{array}{l}\text { Semi-structured } \\
\text { interview }\end{array}$ & Public Hospital & Psychiatrist & $\begin{array}{l}\text { July 2020/ } \\
\text { online } \\
\text { zoom } \\
\text { meeting }\end{array}$ \\
\hline $\begin{array}{l}\text { Informant } \\
5\end{array}$ & $\begin{array}{l}\text { Semi-structured } \\
\text { interview }\end{array}$ & $\begin{array}{l}\text { Ministry of } \\
\text { Health, } \\
\text { Malaysia (KKM) }\end{array}$ & $\begin{array}{l}\text { Senior Principal } \\
\text { Assistant Director }\end{array}$ & $\begin{array}{l}\text { August } \\
\text { 2020/ } \\
\text { online } \\
\text { zoom } \\
\text { meeting }\end{array}$ \\
\hline $\begin{array}{l}\text { Informant } \\
6\end{array}$ & $\begin{array}{l}\text { Semi-structured } \\
\text { interview }\end{array}$ & Public Hospital & Psychiatrist & $\begin{array}{l}\text { August } \\
\text { 2020/ } \\
\text { online } \\
\text { zoom } \\
\text { meeting }\end{array}$ \\
\hline $\begin{array}{l}\text { Focus } \\
\text { group } \\
\text { discussion }\end{array}$ & Focus group & $\begin{array}{l}\text { Public } \\
\text { University }\end{array}$ & $\begin{array}{l}\text { Youth } \\
\text { (university level) }\end{array}$ & $\begin{array}{l}\text { Nov. } \\
2020 / \\
\text { online } \\
\text { zoom } \\
\text { meeting }\end{array}$ \\
\hline
\end{tabular}

Analysis and interpretation of data used interpretative phenomenological analysis (IPA) (Smith \& Osborn, 2007). Typically, IPA researchers will focus on homogeneous samples since this study uses a phenomenological approach because it involves detailed observations and examinations of respondents' life experiences. In addition, IPA provides an analytical framework to understand the context or experiences experienced by respondents. Therefore, 
a small sample selection is very useful for studies conducted using IPA. This allows sufficient in-depth engagement with each respondent by enabling detailed examination related to similarity and difference, convergence and divergence (Pietkiewicz et al., 2014). It should also be noted that performing qualitative data analysis like this requires iterative work instead of linear. It also involves very close interaction between the researcher and the text of the interview transcript. As a qualitative researcher, it requires using interpretative resources to make sense and understand what the respondent is saying. Still, at the same time, the researcher also constantly examines one's thinking on what the respondent is said (Smith, 2007).

This study uses coding analysis with theory-driven and data-driven methods. Initially, the model of informal education theory is used by focusing on the element that occurs in daily life, and informal education occurs unconsciously, without intention, and occurs continuously. So this element is made the next core to relate the data from the respondents to the context of mental health literacy. Then, after finding some suitable data, the researchers also used data-driven methods for the coding research process for the second time (DeCuir-Gunby et al., 2011).

\section{Results ad Discussion}

From the interview sessions conducted, the researchers identified several themes that have been arranged in the following table. The themes refer to understanding mental health literacy, support system, and challenges faced by youth. A summary of the themes and examples of excerpts from the interviews are included in Table 2. Many respondents agreed that mental health literacy depends on the cultural context constructed by communities and informal education agents. Also, the support system and the role of those around the youth is seen as important.

During the interviews, respondents shared their experiences in helping youths manage stress in daily life, thereby improving their mental health literacy. The average respondent stated that the need for a positive psychological approach should be given attention to this group to help them become more proficient in stress management such as basic techniques described by applying good and effective communication and displaying attractive and good character with a smile to the youth. This includes practicing good attitudes such as celebrating a small thing that is in a youth, celebrating the goodness that is in them, and words like this will bring good and positive emotions and then allow them to go through a process of experience sharing and story telling between youth and informal education agents (Informant 1). When discussing communication then it is divided into several ways, among which are synonymous and common these youths interact through cyberspace. The challenges of the digital world in this era allow youths to communicate with each other through multiple social media platforms capable of connecting people and conveying information regardless of distance and location. It also has some effective facilities such as time savings and affordable operating costs (Ridout \& Campbell, 2018). Informal education is able to provide information to youth, especially in daily life. Hence this information needs to be converted into knowledge that can help the youth to manage their daily lives well (Chepkuto et al., 2014). Knowledge related to mental health can only be adapted to changes in the mindset, attitude and behavior of the youth in turn can promote to improve mental health literacy. 
Thus communication through digital sites requires an appropriate approach for adolescents and youth. If this aspect of communication is not managed well, it may lead to misunderstandings such as if a youth sends an email to a friend but the email is not answered or does not get any response for a long time, then there is a misunderstanding and negative perception. This shows that, youths can be affected by routine daily activities, trivial and involving even small things can have an impact on the emotional feelings and mental health levels of youths. Sometimes it can create a feeling as if self is not valued. So communication relationships in the virtual world have their own elements that need to be seen in depth and require techniques that are appropriate to the youth (Levine, 2015). In this situation the youth themselves need to be positive and think maturely. Early youths in adolescence are usually immature in thinking and performing an action that causes them to be very easily influenced by surrounding factors (Rumeli et al., 2021).

This positive psychological method applies to all informal education agents to confront youth in improving mental health literacy (Knefel et al., 2020; Nasharudin et al., 2020). Because youths are very unique and have complicated internal and mental situations, so with the psychological approach it is easier for these informal education agents to face the challenge of understanding the real life situations of youths. This is seen as important because to more easily reach out to the youth and make it easier for them to share problems and stories with other informal education agents. What is important is that the psychological approach that should be used by informal education agents is to bring a sense of comfort to young people and it will lead to steps of knowledge sharing sessions, skills, and attitude formation towards improving mental health literacy.

When this process can be perfected to the youth, then this can facilitate the process in changing their thinking and mindset to take appropriate action in improving mental health literacy. The appreciation given to this group, though small but for the youth it is very important to present a sense of excitement (Ariffin et al., 2017). When they get a response, appreciation, praise from others, they will be easier to approach. Therefore youth should be approached with a more comprehensive approach and full of awesomeness to instill a strong sense of motivation and desire for them to take practical steps for improving mental health literacy.

Next things need to be discussed in the context of informal education in an ongoing manner. The efforts and roles carried out by informal agents education need to be implemented continuously in life. It cannot be carried out in phases but it encompasses from all aspects of activities in daily life. Implemented by the government and non-government and when it does not involve a specific time frame, it is in line with the characteristics of informal education which is different from the philosophy and nature of formal education that is time-based. The life activities of young people are synonymous with the informal education agents mentioned in the table below such as the example of social media that brings and shapes influence to the youth. therefore these challenges need to be overcome and played a role to be harnessed towards the development and improvement of their mental health literacy. 
Table 2. Summary of Themes Identified in the Interview and Sample Excerpts

\begin{tabular}{|c|c|c|c|}
\hline Theme & Code & Description & Quotes example \\
\hline \multirow[t]{3}{*}{$\begin{array}{l}\text { The role of } \\
\text { informal } \\
\text { education agents }\end{array}$} & Family & $\begin{array}{l}\text { Family } \\
\text { members } \\
\text { provide } \\
\text { emotional } \\
\text { support and } \\
\text { social therapy } \\
\text { to other } \\
\text { members }\end{array}$ & $\begin{array}{l}\text { "...Psychology is health education, } \\
\text { psychotherapy, we empathise with } \\
\text { social therapy. This social therapy } \\
\text { means family, community support, } \\
\text { we empathise with recovery, } \\
\text { empathise with work, finances, } \\
\text { accommodation" (Informant 4). } \\
\text { "...Because, for me, the factor that } \\
\text { really affects a youth is the first } \\
\text { family, because I have met a family } \\
\text { that behaves strangely. Not normal, } \\
\text { it may not be normal. The second } \\
\text { factor is financial, and the third factor } \\
\text { is a relationship such as a love } \\
\text { relationship, It's normal for young } \\
\text { people to have a lot of problems..." } \\
\text { (Informant 2). }\end{array}$ \\
\hline & NGO & $\begin{array}{l}\text { NGOs } \\
\text { promote } \\
\text { mental health } \\
\text { management } \\
\text { methods and } \\
\text { other } \\
\text { activities } \\
\text { related to } \\
\text { mental health } \\
\text { literacy }\end{array}$ & $\begin{array}{l}\text { "...there are part of Laman Minda, we } \\
\text { have NGOs, there are also their have } \\
\text { their own face book, Mental Health } \\
\text { Association Sarawak, he has his own } \\
\text { face book, MIASA he has his own face } \\
\text { book, then another one is a group } \\
\text { that we say help line. This is the } \\
\text { helpline. So like this Befrienders, let's } \\
\text { say like we need someone to talk to } \\
\text { we encourage people Befrienders" } \\
\text { (Informant 4). }\end{array}$ \\
\hline & Peers & $\begin{array}{l}\text { Among the } \\
\text { actions } \\
\text { required from } \\
\text { peers are } \\
\text { socialising } \\
\text { others, keep } \\
\text { asking } \\
\text { common } \\
\text { dialogue, } \\
\text { active } \\
\text { listening/ } \\
\text { listen }\end{array}$ & $\begin{array}{l}\text { "...Peers play a very important role. } \\
\text { Our university also got peer } \\
\text { counselling in volunteers. We train } \\
\text { them to be counsellors as peers ... in } \\
\text { a way for me the peer counsellor is a } \\
\text { classroom setting, but it can also } \\
\text { be..." (Informant 1). }\end{array}$ \\
\hline
\end{tabular}




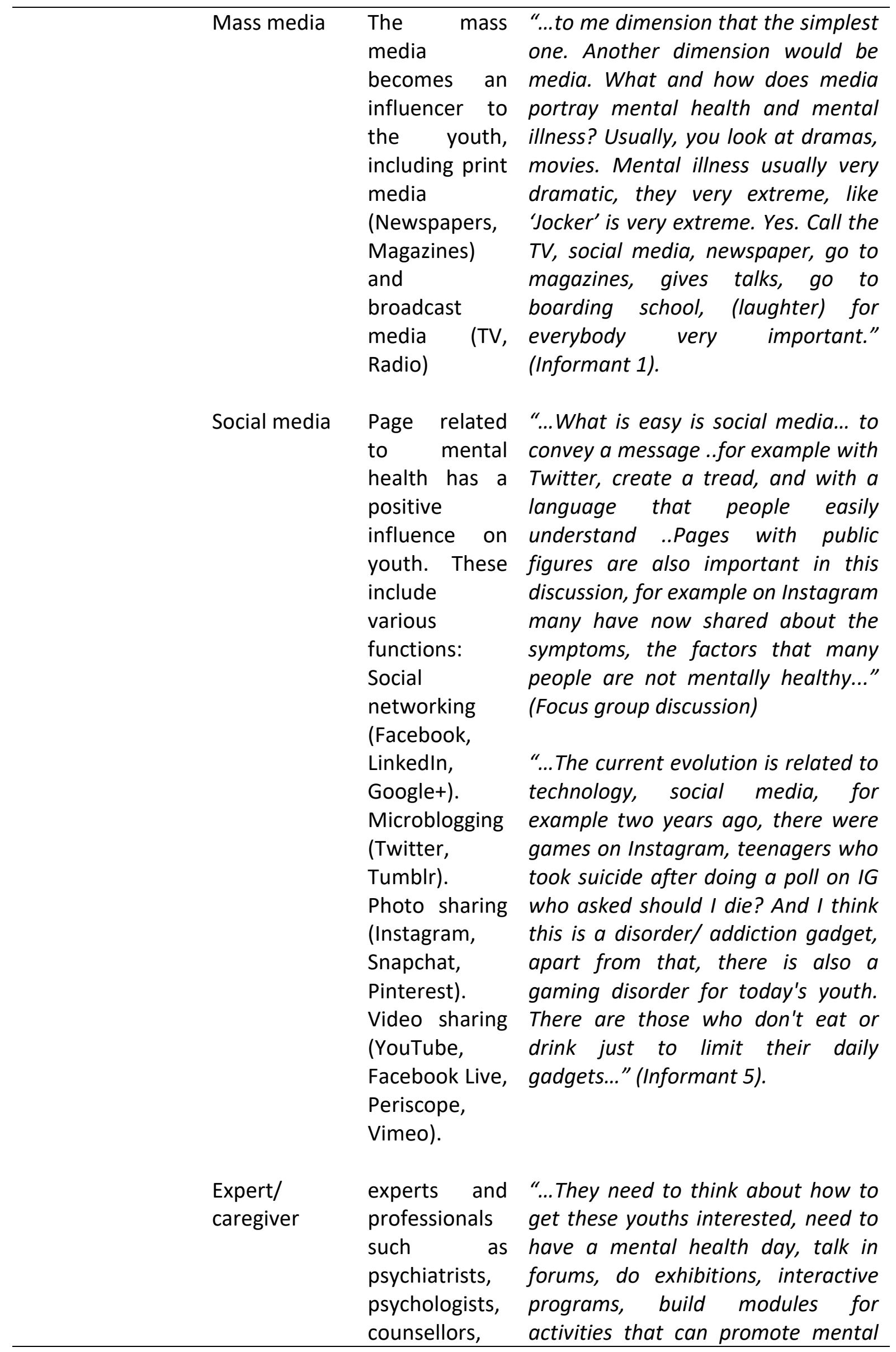




\begin{tabular}{|c|c|c|c|}
\hline & & $\begin{array}{l}\text { ministry } \\
\text { officers act } \\
\text { actively by } \\
\text { performing } \\
\text { the process of } \\
\text { recognising, } \\
\text { acknowledge } \\
\text { and contribute }\end{array}$ & $\begin{array}{l}\text { health literacy... these people also } \\
\text { need to do something that can and is } \\
\text { easy achieved by the public, } \\
\text { encourage them..." (Informant 3). }\end{array}$ \\
\hline \multirow[t]{4}{*}{$\begin{array}{l}\text { Mental health } \\
\text { literacy } \\
\text { conceptualisation }\end{array}$} & Daily life & $\begin{array}{l}\text { It happens and } \\
\text { is very close in } \\
\text { daily activities }\end{array}$ & $\begin{array}{l}\text { "...Thus, this mental health literacy is } \\
\text { encompassing our daily lives, how } \\
\text { one manages oneself, manages time, } \\
\text { communicates with others, the } \\
\text { function of daily activities can be } \\
\text { implemented to be productive..." } \\
\text { (Informant 6). }\end{array}$ \\
\hline & $\begin{array}{l}\text { Normalisation } \\
\text { process }\end{array}$ & $\begin{array}{l}\text { Every effort to } \\
\text { make the topic } \\
\text { of mental } \\
\text { health literacy } \\
\text { commonplace } \\
\text { in the } \\
\text { community is } \\
\text { needed. }\end{array}$ & $\begin{array}{l}\text { "...We have to correct the wrong } \\
\text { ideas then we have to make this topic } \\
\text { of mental health normalise because... } \\
\text { 'make mental health a topic at coffee } \\
\text { talk' so people will sit at the coffee } \\
\text { shop, he is not just a story about a } \\
\text { mass he will tell me about having } \\
\text { mental problems like this like this } \\
\text { people will normalise the topic of } \\
\text { mental health..." (Informant 4). }\end{array}$ \\
\hline & $\begin{array}{l}\text { Cultural } \\
\text { appropriation }\end{array}$ & $\begin{array}{l}\text { Continuous } \\
\text { effort on } \\
\text { cultural and } \\
\text { tradition } \\
\text { construction } \\
\text { by the } \\
\text { community }\end{array}$ & $\begin{array}{l}\text { "...he has a different kind of culture. If } \\
\text { he reads there, he is not ashamed. He } \\
\text { seems to want to tell 'I have my } \\
\text { psychiatrist', if here our culture is to } \\
\text { let people know that we have } \\
\text { received treatment, it will be a kind of } \\
\text { shame. So it's our culture ... the } \\
\text { Malaysian culture itself..." (Informant } \\
\text { 1). }\end{array}$ \\
\hline & Help-seeking & $\begin{array}{l}\text { All actions and } \\
\text { activities that } \\
\text { lead to the } \\
\text { search for help } \\
\text { when stressed }\end{array}$ & $\begin{array}{l}\text { "Usually I go to see professionals, } \\
\text { apart from that, I can also see } \\
\text { Mentors or seniors who are older } \\
\text { than us and I am also used to when I } \\
\text { sleep stress, I think it's my therapy. in } \\
\text { the evenings, jog with friends, do } \\
\text { physical activities, and most of all, } \\
\text { share stories with close friends." } \\
\text { (Focus group discussion) }\end{array}$ \\
\hline
\end{tabular}


"...In addition, teenagers also need to
engage in healthy activities such as
sports to achieve physical and mental
health. The role of friends to create a
good environment must be open and
for example, if teenagers are
studying, they need to manage time,
sometimes sleep or even think too
much. Can cause mental health
problems..." (Informant 6).

\section{Conclusions}

There are various ways available from the environment and informal educational agents to enhance knowledge, attitudes and practice. To enhance mental health literacy, all of them set a good role model and an ideal balanced paradigm at all levels of the organism. When all these interact with each other, mental health literacy will increase. Mental health problems often misunderstood and seen as poorly perceived will eventually find an appropriate solution. Considerations related to the involvement of informal education agents are reunification of existing roles to help youth improve mental health literacy. With the availability of scientific studies related to the role of informal education agents like this, then the public will get a clear understanding to improve and expand the assistance of this multidisciplinary support team. Bad stigma and wrong perceptions of mental health can be reduced and create good and physically and mentally healthy youth and a more prosperous community. Mobilisation to all parties needs to be compatible and balanced and achieve the same goals.

\section{Conflict of Interest}

The authors declare that they have no competing interest in conducting this study.

\section{Acknowledgements and Funding}

The authors would like to thank all the individuals who participated in this study. This work was supported by the Ministry of Education Malaysia, under Fundamental Research (FRGS, Phase 1/2019- FRGS/1/2019/SS06/UPM/02/10), and Universiti Putra Malaysia.

\section{References}

Ariffin, Z., Krauss, S. E., Abdullah, H., Ortega, A., \& Ali, Z. (2017). Peer Support and Youth Engagement. International Journal of Academic Research in Business and Social Sciences, 7(8), 629-634. https://doi.org/10.6007/ijarbss/v7-i8/3268

Backett-Milburn, K. (2000). Understanding peer education: insights from a process evaluation. Health Education Research, 15(1), 85-96. https://doi.org/10.1093/her/15.1.85

Bavarian, N., Ph, D., Johnson, A., Ph, D., Chun, C., \& Ph, D. (2020). Informal Mental Health Help-Seeking Behaviors Among Asian American College Students (Issue May).

Berry, C., Othman, E., Tan, J. C., Gee, B., Byrne, R. E., Hodgekins, J., Michelson, D., Ng, A. L. O., Marsh, N. V., Coker, S., \& Fowler, D. (2019). Assessing social recovery of vulnerable youth in global mental health settings: A pilot study of clinical research tools in Malaysia. BMC 
Psychiatry, 19(1), 1-13. https://doi.org/10.1186/s12888-019-2164-x

Chan, C., Embi, M., \& Hashim, H. (2019). Primary School Teachers' Readiness Towards Heutagogy and Peeragogy. Asian Education Studies, 4, 11. https://doi.org/10.20849/aes.v4i1.602

Chepkuto, P., Ombongi, J., \& Kipsang, S. (2014). The Role of Education in Fostering Peace, Solidarity and Prosperity in Kenya. International Journal of Academic Research in Business and Social Sciences, 4(8), 346-355. https://doi.org/10.6007/ijarbss/v4-i8/1103

Clarke, A. M., Kuosmanen, T., \& Barry, M. M. (2014). A Systematic Review of Online Youth Mental Health Promotion and Prevention Interventions. Journal of Youth and Adolescence, 44(1), 90-113. https://doi.org/10.1007/s10964-014-0165-0

Clegg, T., Boston, C., Preece, J., Warrick, E., Pauw, D., \& Cameron, J. (2020). Community-driven informal adult environmental learning: Using theory as a lens to identify steps toward concientización. Journal of Environmental Education, 51(1), 55-71.

https://doi.org/10.1080/00958964.2019.1629380

DeCuir-Gunby, J. T., Marshall, P. L., \& McCulloch, A. W. (2011). Developing and using a codebook for the analysis of interview data: An example from a professional development research project. Field Methods, 23(2), 136-155. https://doi.org/10.1177/1525822X10388468

Delprino, R. P. (2017). Understanding and Supporting Law Enforcement Families: An Applied Research Perspective. Lexington Books.

https://books.google.com.my/books?id=nDpJDwAAQBAJ

Farahani, M. F., Mirzamohamadi, M. H., \& Noroozi, N. (2014). The Study on Features of Informal Education in Postmodernism. Procedia - Social and Behavioral Sciences, 136, 559-563. https://doi.org/10.1016/j.sbspro.2014.05.376

Hannan, R. (2013). The Triangle of Care: Carers included. Journal of Public Mental Health, 12(3), 171-172. https://doi.org/10.1108/JPMH-06-2013-0042

Hui, A., Wong, P. W., Fu, K., \& Hall, E. (2015). Evaluation of an Online Campaign for Promoting Help-Seeking Attitudes for Depression Using a Facebook Advertisement: An Online Randomized Controlled Experiment Corresponding Author: JMIR MENTAL HEALTH, 2. https://doi.org/10.2196/mental.3649

Johnson, C. (2017). The Impact Of Informal Education On Formal Education In Science A Symbiotic Relationship. https://digitalcommons.hamline.edu/hse_all/4342

Jones, A., Hannigan, B., Coffey, M., \& Simpson, A. (2018). Traditions of research in community mental health care planning and care coordination: A systematic meta-narrative review of the literature. PLOS ONE, 13(6), 1-23. https://doi.org/10.1371/journal.pone.0198427

Kauer, S. D., Mangan, C., Sanci, L., \& Kauer, S. D. (2014). Do Online Mental Health Services Improve Help-Seeking for Young People? A Systematic Review Corresponding Author: 16, 1-18. https://doi.org/10.2196/jmir.3103

Kelly, C. M., Jorm, A. F., \& Wright, A. (2007). Improving mental health literacy as a strategy to facilitate early intervention for mental disorders. 187(7), 1-5.

Knefel, M., Kantor, V., Nicholson, A. A., Schiess-Jokanovic, J., Weindl, D., Schäfer, I., \& LuegerSchuster, B. (2020). A brief transdiagnostic psychological intervention for Afghan asylum seekers and refugees in Austria: a randomized controlled trial. Trials, 21(1), 57. https://doi.org/10.1186/s13063-019-3839-9

Lam, L. (2014). Mental health literacy and mental health status in adolescents: A populationbased survey. Child and Adolescent Psychiatry and Mental Health, 8, 26.

https://doi.org/10.1186/1753-2000-8-26 
Larsen, J. K. (1987). Community mental health services in transition. Community Mental Health Journal, 23(4), 250-259. https://doi.org/10.1007/BF00769837

Levine, A. (2015). Exploring the Frontier of Virtual Worlds. November.

Lizzio, A., Dempster, N., \& Neumann, R. (2011). Pathways to formal and informal student leadership: The influence of peer and teacher-student relationships and level of school identification on students' motivations. International Journal of Leadership in Education, 14. https://doi.org/10.1080/13603124.2010.482674

Mandalia, D., Ford, T., Hill, S., Sadler, K., Vizard, T., Goodman, A., Goodman, R., \& Mcmanus, S. (2018). MHCYP - Professional services, informal support, and education. November. https://files.digital.nhs.uk/8E/AAB376/MHCYP 2017 Service Use.pdf

Marsick, V. J., \& Watkins, K. E. (2001). Informal and Incidental Learning. New Directions for Adult and Continuing Education, 2001(89), 25. https://doi.org/10.1002/ace.5

Ministry of Education Malaysia. (2013). Malaysia Education Blueprint 2013 - 2025 (Vol. 27, Issue 1). http://linkinghub.elsevier.com/retrieve/pii/S0742051X10001435

Ministry of Education Malaysia. (2015). Malaysia Education Blueprint 2015-2025. 2025.

Ministry of Health Malaysia. (2013). Community Mental Health Centre Implementation Guideline. http://library1.nida.ac.th/termpaper6/sd/2554/19755.pdf

Mpungose, C. B. (2020). Are social media sites a platform for formal or informal learning? Students' experiences in institutions of higher education. International Journal of Higher Education, 9(5), 300-311. https://doi.org/10.5430/ijhe.v9n5p300

Muhamad Nasharudin, N. A., Idris, M. A., Loh, M. Y., \& Tuckey, M. (2020). The role of psychological detachment in burnout and depression: A longitudinal study of Malaysian workers. Scandinavian Journal of Psychology, 61(3), 423-435.

https://doi.org/10.1111/sjop.12622

Pietkiewicz, I., Smith, J. A., Pietkiewicz, I., \& Smith, J. A. (2014). A practical guide to using Interpretative Phenomenological Analysis in qualitative research psychology. Czasopismo Psychologiczne Psychological Journal, 20(1), 7-14. https://doi.org/10.14691/cppj.20.1.7

Pretorius, C., Chambers, D., \& Coyle, D. (2019). Young People's Online Help-Seeking and Mental Health Difficulties: Systematic Narrative Review Corresponding Author: 21. https://doi.org/10.2196/13873

Richards, D., \& Tangney, B. (2008). An informal online learning community for student mental health at university: A preliminary investigation. British Journal of Guidance and Counselling, 36(1), 81-97. https://doi.org/10.1080/03069880701715671

Ridout, B., \& Campbell, A. (2018). The Use of Social Networking Sites in Mental Health Interventions for Young People: Systematic Review Corresponding Author : 20, 1-11. https://doi.org/10.2196/12244

Rumeli, M. S., Arshad, M. M., Ismail, I. A., \& Aizuddin, A. (2021). Youth Leadership Development through Training Transfer and Mentoring Youth Leadership Development through Training Transfer and Mentoring. 1(15). https://doi.org/10.6007/IJARBSS/v11i15/10652

Smith, J A. (2007). Qualitative Psychology: A Practical Guide to Research Methods. SAGE Publications. https://books.google.com.my/books?id=D5xHYpXVDaAC

Smith, Jonathan A., \& Osborn, M. (2007). Intrepretive Phenomenological Analysis. Qualitative Psychology: A Practical Guide to Research Methods, 51-80.

Tay, J. L. (2018). Effectiveness of information and communication technologies interventions to increase mental health literacy: A systematic review. April, 1024-1037. 
https://doi.org/10.1111/eip.12695

Tennant, B., Stellefson, M., Dodd, V., Chaney, B., Chaney, D., Paige, S., \& Alber, J. (2015). eHealth literacy and Web 2.0 health information seeking behaviors among baby boomers and older adults. Journal of Medical Internet Research, 17(3), e70. https://doi.org/10.2196/jmir.3992

Tudor, S. L. (2013). Formal - Non-formal - Informal in Education. Procedia - Social and Behavioral Sciences, 76, 821-826. https://doi.org/10.1016/j.sbspro.2013.04.213

World Health Organization. (2013). Mental health action plan 2013-2020. 